\title{
An Overview of Occupational Safety and Health Systems in Nigeria
}

\author{
Qudus Olawepo \\ ORCID iD: https://orcid.org/0000-0002-5210-5627
}

Mariam Seedat-Khan

ORCID iD: https://orcid.org/0000-0001-9056-2282

\author{
Stanly Ehiane \\ ORCID iD: https://orcid.org/0000-0001-6871-4526
}

\section{Abstract}

The International Labour Organisation (2019) has developed numerous conventions, protocols, and recommendations on minimum labour standards. Some conventions have been promulgated and adopted by the ILO member states, the majority of which relates to occupational safety and health systems $(\mathrm{OSH})$. This study evaluates the OSH in Nigeria to ascertain their compliance with ILO safety standards. The evaluation continued with a focus on the OSH in the food and drink sector in Nigeria. The legislation that institutes the underpinnings of the OSH system was examined against the industry in Nigeria. The critique recognised that Nigeria, analogous to other African countries, had not ratified the principal ILO conventions on safety and health in particular. The ILOC155 (1981) and ILO promotional framework for occupational safety and health convention (ILOC187 2006). The exploration of the OSH systems demonstrates that OSH systems in Nigeria are largely uncoordinated and weak owing to administrative, human, technological and logistics limitations. Convention 187 (ILOC187 2006) requires of ratifying member countries to formulate national OSH policies, systems, and programmes to prevent industrial accidents and minimise hazardous conditions in the workplace. Unambiguously, the convention makes it mandatory for all country signatories to implement a coherent national OSH. This study esta- 
blished that Nigeria was among one of the signatories in Africa who had failed to comply with this directive.

Keywords: Drink, Food, Manufacturing, Nigeria, Regulation, Safety System

\section{Introduction}

The manufacturing sector in Nigeria comprises roughly 13 distinctive subsectors. In 2013, the food, beverage and tobacco sub-sector were the three most significant contributors to the country's gross domestic product (GDP) in the manufacturing sector, with a $52.74 \%$ contribution to the GDP (National Bureau of Statistics 2014). Notwithstanding this significant financial contribution, the manufacturing industry in Nigeria has been portrayed as hazardous for workers as a result of persistent accidents. These accidents are undoubtedly due to inattentive governmental regulations in the food manufacturing sector. The food and beverage sub-sector dominated the manufacturing industry, contributing $72.02 \%$ of the total manufacturing output in 2013 , tracked by textiles, apparel and footwear (NBS 2014). In 2013, the manufacturing sector accounted for the employment of 2368514 persons, of which over $80 \%$ held permanent positions (NBS 2014). Nigeria is a signatory on two international labour organisation (2019) conventions, including conventions on OSH, since the country's formal affiliation with the international body in 1960. In the same way, Nigeria is a signatory to the Co45 underground work (women) convention (ILOC045 1935), which came into effect on 17 October 1960. Nigeria is correspondingly a signatory to C155-occupational safety and health convention, (ILOC155 1981), which came into force on 3 May 1994. Nigeria presently has nine legislation on OSH (ILO 2016) designed to support and protect workers in the manufacturing sector.

The promulgation of the safety ordinance of 1955 was the Nigerian government's first attempt to regulate industrial organisations (Uvieghara 2001). OSH procedures were institutionalised by a series of legislations that were promulgated during the 1970s (Umeokafor et al. 2014b; Wekoye, Moturi \& Makindi 2019; Fuller 2019; Manu et al. 2019; Simukonda et al. 2020). The Factory Act of 2004 (OSHP 2004) is the principal statute that regulates OSH in Nigeria. The Employees' Compensation Act of 2010 specifies the compensation of employees that suffer varying severity of work-related injuries. The 
Labour, Safety, Health and Welfare Bill of 2012 is the most recent legislation that seeks to repeal The Factory Act of 2004. The law was passed as a bill by the two national parliamentary assemblies in 2012 (Umeokafor et al. 2014b; Reuben et al. 2019; Wekoye et al. 2019; Omoijiade 2019; Nkuhi \& Benjamin 2020; Umeokafor et al. 2020; Okoye, Ezeokonkwo \& Ezeokoli 2016). Scholars have reported that the enforcement of OSH laws in Nigeria is relatively inadequate (Idoro 2011; Umeokafor et al. 2014b; Abubakar 2015; Bamel, Pandey \& Gupta 2020; Hallowell, Bhandari \& Alruqi 2019). The manufacturing sector had recorded perennial accidents (Victor 2013). Between 1987 and 1996, 3183 injuries were reported in Nigeria, of which 71 (2.2\%) were fatal (Ezenwa 2001; Osman et al. 2019; Kidd 2020; Simukonda et al. 2020; Supriyatna, Kurniawan \& Purba 2020). The accident statistics, according to a statement presented to the national OSH information centre (CIS) in 2006, revealed that 490 industrial accidents were reported in Nigeria between 2001 and 2006. Umeokafor et al. (2014a) report that based on the accident report from the federal ministry of labour and productivity (FMLP), evidence indicates that the food processing sector recorded $60 \%$ of all fatal cases between 2002 and 2012. The findings confirm that the food processing sector had the second-highest number of reported accidents after the rubber products manufacturing sector. The food processing sector recorded ' 9 accidents $(22.5 \%), 12$ deaths, 20 injuries and a fatality case of 60\%' (Umeokafor et al. 2014a: 112).

\section{Table1: Record of accidents, injuries and deaths in the industry}

\begin{tabular}{|l|c|c|c|}
\hline & 1987-1996 & 2001- 2006 & 2002-2012 \\
\hline Accidents & & 490 & 9 \\
\hline Injuries & 3183 & & 20 \\
\hline Death & 71 & & 12 \\
\hline
\end{tabular}

This study therefore validly examines the OSH in the food and drink industry in Nigeria. Firstly, international safety standards and best practices in OSH will be studied, following which, the paper will survey and liken safety standards in Africa broadly and Nigeria accurately. Finally, the national framework on $\mathrm{OSH}$, including national policies on occupational safety, legislations and government regulations in Nigeria will be examined. This will be prepared to determine the setting of the industrial safety system in the food and drink industry in Nigeria. The scholarship is theoretical, and as such, literature on 
international conventions on OSH is exposed. The main ILO (2020) conventions on OSH are accentuated and considered. This proceeds to an added review of OSH in Nigeria, Africa and internationally, with emphasis on the IR system in the food and drink industry in Nigeria, particularly, safety systems, trade disputes and resolutions.

\section{International Conventions on Occupational Safety and Health}

The international conventions, protocols, and recommendations are international legal instruments that are proposed by global and regional organisations that form part of the supra-legal frameworks for member countries to adopt. The international legal instruments do not have the power of force except when a member country ratifies such legal instrument and it can be reviewed after ten years on a notice appropriately given by the rectifying member state. The International Labour Organization (ILO) was established in 1919 (Machida 2009). The ILO is a significant body that regulates the minimum labour standards around the world. As of 14 March 2020, the ILO consists of 187 member states (ILOC187 2006). According to O'Connor (2014), 'between 1919 and 2012, 189 conventions, five protocols and 202 recommendations were adopted; many of these instruments relate to occupational safety and health'. According to the ILO, 399 instruments of the organisation had been adopted by member states: 189 conventions, six protocols and 204 recommendations (ILO 2020: 19). In a move to determine the status of the international legal framework with member country laws, the Argentine Supreme Court upheld that international legal instruments take precedence over member countries' national laws. In a fatal industrial occurrence that involved a worker falling from a rooftop, which had initially been decided by a lower court and appealed at the Supreme Court over the hierarchy of the country laws, specifically the risks in the Workplace Act (LRT) No. 24557 (ITC 2004) and that of international legal instruments, the court ruled,

The LRT System called into question was not in harmony with another principle landmark of the National constitution of the Federal Republic of Nigeria (1999) and international laws on human rights: social justice, which has important application in the field of labour law and was embodied at the beginning of the last century in the preamble to the constitution of the international labour organisation as a means towards 
establishing universal peace, but also as an end in itself. Among many international instruments, the preamble to the charter of the organisation of the American States and the American Convention on Human Rights, in their turn, have ceased to proclaim and adhere to this principle, which also appears in art. Thirty-four of the above charter (as the Protocol of Buenos Aires). However, it is unnecessary even to turn to those because social justice as clarified by this court in the exemplary 'BerCaitz' case was already present in our constitution from the very beginning (ITC 2004).

To emphasise the principles espoused in the case above, the charter that established the ILO indicates that the object of providing minimum labour standards for workers over the world is a means to achieve world peace, as stated in Part XIII of the Treaty of Peace of Versailles (quoted in O'Connor 2014). Part XIII section states,

Whereas the league of nations has for its object the establishment of universal peace, and such a peace can be established only if it is based upon social justice. However, harsh conditions of labour involving injustice, hardship and privation to large numbers of workers. These conditions produce unrest so volatile that the peace and harmony of the world are imperilled. An improvement of the harsh conditions is urgently necessitated. In the instance, of regulations of hours, per worker per day and week, to regulate the labour supply. The industry and country are also responsible for the avoidance of unemployment, the establishment of an adequate living wage, the protection of the worker against preventable illness, disease and occupational injury. These rights, coupled with the commitment to the protection of children, young persons and women, provision for old age and injury and the protection of workers interests employed outside the country. Ultimately the recognition of the principle of association, the organisation of vocational and technical education and measures need to be established in the interest of the workforce.

In 1999 and 2005, the ILO carried out a series of studies on global estimates of occupational safety and diseases from an extrapolation of regional and country-based occupational accident and diseases databases (Talaka 1999; 
Talaka 2005; Hamalainen, Talaka \& Saareta 2006; Pearson 2009; O’Connor 2014; Tella \& Ibinaiye 2020; Nyarubeli et al. 2020; Barros, Dores \& Rodrigues 2020). The 1999 estimates were based on 1994 average estimates using the ILO member states' reports on fatal and non-fatal occupational accidents reports. Talaka (1999) reports global fatality rates of 335000 and 250 million non-fatal occupational accidents. Another study by Hamalainen et al. (2006) expand the database to include the ILO yearbook of labour statistics, Eurostat and national statistics. The ILO 2005 report shows that a range of 2.0-2.4 million annual work-related mortality, the mid-point being 2.2 million. Besides, the report indicates that 270 million non-fatal occupational accidents and 160 million work-related diseases were estimated to occur annually. The study has established that the ILO conventions and other instruments have a higher status in the legal hierarchy of members states once ratified. This section presents summaries of relevant ILO instruments relating to occupational safety and health (NOSH 2016). The applicable ILO conventions include the ILO Guarding of Machine Convention,1963 (ILOC119 1963); ILO Workmen's compensation (Accidents) Convention, (ILOC017 1925); ILO Occupational Safety and Health Convention, 1981 (ILOC155 1981); ILO Promotional Framework for Occupational Safety and Health Convention, 2006 (ILOC187 2006); ILO Recommendation on Protection of Workers' Health, 1953 (ILOR097 1953); and ILO Asbestos Recommendation, 1986 (ILOR721 1986).

\section{ILO Guarding of Machinery Convention, 1963 (Number. 119)}

The convention seeks to ban the sale, hire and transfer of all power-driven machinery, whether new or second-hand without appropriate protective guards. The convention consists of six parts with 25 articles. Article 3 of the convention specifies that the provisions apply only to the road and vehicle; and agricultural machinery. Article 3 paragraph 1(a)(b) states that the requirements of the convention are,

a) Apply to road and rail vehicles during locomotion only concerning the safety of the operator or operators; b) Apply to mobile agricultural machinery only concerning the safety of workers employed in connection with such machinery.

The responsibilities of ensuring that only types of machinery with 
appropriates guards are sold, leased and transferred are on the manufacturer or vendors according to Article 4 of the convention. Articles 10 (1) and (2) made it mandatory for employers to instruct their workers in their employ on the proper handling of the machines and to ensure that the machine guards are installed. Article 2 para 4 states,

All flywheels, gearing, cone and cylinder friction drives, cams, pulley, belts, chains, pinions, worn gears, crank arms and slide blocks, and, to the extent prescribed by the competent authority, shafting (including the journal ends) and other transmission machinery also liable to present danger to any person coming into contact with them when they are in motion, shall be so designed or protected as to prevent such danger, control also shall be designed or protected as to prevent danger.

As of 14 March 2020, guarding of machinery convention, 1963 (ILOC119 1963). According to ILO online bulletin, 52 countries have ratified the convention since 1963 .

\section{Occupational Safety and Health Convention, 1981 (Number 155)} According to ILO (2020), the occupational safety and health convention, number 155 was adopted by the governing body of the ILO office on 22 June 1981 (ILOC155 1981). The convention came into force on 11 August 1983. The convention consists of 5 parts with 30 articles. The convention aims to formulate national policies on $\mathrm{OSH}$ for member countries with the view to prevent industrial accidents and to minimise hazardous conditions as reasonably as possible. According to the ILO online bulletin, 66 member countries have ratified the convention since it came into force. Fifteen African countries have ratified the convention, including Nigeria, South Africa, Central Africa Republic, Cote d'Ivoire, Gabon, Ethiopia, Lesotho, Mauritius, and Niger, among others. A total of 121 ILO members are yet to ratify the convention.

Part one of the convention covers the scope and definitions of pertinent terms. Part two includes the general character of OSH policies for member countries while parts three and four centre on the implementation of the policies at national and enterprise levels, respectively. The final section covers the general provisions of the convention. Parts one and two cover the scope of 
the convention. According to part two, the convention covers every economic sector, including the public sector. However, ratifying members may apply to the director of the ILO for the exclusion of specific sectors such as maritime shipping or fishing (Art. 1). Article 4 makes it mandatory for ratifying members to implement coherent OSH national policies. Such a strategy will aim to prevent workplace accidents.

Furthermore, article 8 makes it compulsory for ratifying members to ensure that the provisions of the convention come into force once adopted. Specifically, article 8 states that approving members should institute an adequate system of inspection. Besides, part 12 provides that such an inspection system should ensure the safeguarding of equipment and types of machinery at the enterprise and minimise hazardous conditions. Part IV of the Convention specifies employers' roles in the OSH system at the enterprise level of ensuring a safe working environment without any financial contribution from the workers. Finally, article 19 of the convention specifies the roles of workers in the OSH system at enterprise level.

\section{Promotion of Framework for Occupational Safety and Health Convention, 2006 (Number 187)}

According to ILO (2020), The Promotion of Framework for Occupational Safety and Health Convention, Number 187 (ILOC187 2006) was adopted by the governing body of the ILO office on 15 June 2006. It came into force on 20 February 2009. The convention consists of six parts with 14 articles. The primary objective of the convention is to promote preventive $\mathrm{OSH}$ among members' countries through provisions on the establishment of national policy, national system and national programme on OSH. According to the ILO online bulletin, 40 member countries, five of which are from Africa, have ratified the conventions since it came into force. A total of 127 member countries are yet to ratify the convention, including Nigeria. Part one and two of the convention cover basic definitions and objectives, respectively. Part 3 encompasses national policy; the national system is found in part 4; and part 5 is focused on the national programme, while the final provisions are concentrated on in part 6. Article 3 para 1 makes it mandatory for ratifying member countries to develop, promote and review national OSH policy. Besides, article 4 para 1 makes it mandatory for ratifying member countries to 'establish, maintain and develop a progressive national system for $\mathrm{OSH}$, in consultation with accredited 
representative organisations of employers and workers'. Furthermore, article 4 para 2 itemises the composition of the national system to include laws and regulations; regulatory bodies, and structures for implementing OSH policies. Besides, article 4 para 3 further states the specifics of the national system to include the following seven key areas.

1. The national tripartite advisory body, or bodies addressing occupational safety and health issues;

2. Information and advisory services on occupational safety and health;

3. Occupational health services following national laws and practices;

4. Research on occupational safety and health;

5. A mechanism for the collection and analysis of data on occupational injuries and diseases, considering relevant ILO Instruments.

6. Provisions for collaboration with relevant insurance or social security schemes covering occupational injuries and disease; and

7. Support mechanisms for a progressive improvement of occupational safety and health conditions in micro-enterprises, in small and medium-sized enterprises and the informal economy.

Finally, part 5 makes provision for the promotion of national OSH programmes by ratifying member countries.

\section{Occupational Safety and Health Systems in Africa}

According to Pearson (2009), most countries have an inadequate reporting system, especially in developing countries. He posits that ILO estimates a 2.2 million fatality rate of work-related death, which is comparable to a small county population, showing the global picture of the incidents. Also, the cost associated with occupational accidents and fatalities had been estimated to be approximately 4\% of the world's Gross Domestic Products (GDP) of US\$2.8 trillion annually. Moreover, the Competitive Report and the ILO data show that countries with lower accident rates also tend to be the most competitive. Developing countries do not invest so much in social development, compared to the global north. The Human Development Index report (United Nations Development Programme 2019.) shows that most developing countries, especially Brazil, China, India, Indonesia, South Africa, and Turkey, have made tremendous economic leaps in recent years. Other smaller countries 
reported having made great economic leaps include Bangladesh, Chile, Ghana, Mauritius, Rwanda and Tunisia (Hammarskjold 2013). Despite the economic achievements of these developing countries, the human development index (HDI) values of these countries were low compared to the industrialised countries. The HDI measures three social investment indicators, i.e. life expectancies, educational attainment and countries' control over economic resources. Other subsidiary indices include inequality, poverty and gender deficit. The report shows that industrialised countries such as Norway ranked number 1, the United States ranked number 3, Germany ranked number 5, Sweden ranked number 7, while the United Kingdom ranked number 26 and had very high human development index HDI values. A few African countries such as Libya ranked number 64, Mauritius ranked number 80, Algeria ranked number 93 and Tunisia ranked number 94 and had high HDI values. Additional countries such as Gabon ranked number 106, Egypt ranked number 112, Botswana ranked number 119, South Africa ranked number 121, Namibia ranked number 128, Ghana, ranked number 135 and Swaziland ranked number 141 and had medium HDI values. The majority of the Africa countries such as Cameroon ranked number 150, Nigeria ranked number 153, Lesotho ranked number 158, Togo ranked number 159, while Zimbabwe ranked number 172 and had low HDI values.

\section{Occupational Safety and Health System in Nigeria}

Occupational safety and health system in Nigeria dates to the $18^{\text {th }}$ century during the British colonial adventure and their involvement in the slave trade in the then western coast of Africa (Kalejaye 2013; Umeokafor et al. 2014b; Ojo 2020; Umeokafor, Evangelinos \& Windapo 2020; Che Ibrahim \& Belayutham 2020; Uchendu, Windle \& Blake 2020b; Osunwusi 2020; Kakwagh 2020). The Military adventurers established the Medical Examination Board of the Liverpool infantry in 1789 to curtail the spread of malaria plaque affecting the troop (Kalejaye 2013). At the dawn of the $20^{\text {th }}$ century, the OSH system had been formally instituted through the promulgation of safety ordinance of 1955 (Uvieghara 2001). The directive was modelled after the British factories' act of 1937 (Uvieghara 2001; Umeokafor et al. 2014b; Omokhodun 2009) and the establishment of the occupational health unit in the Federal Ministry of Health and the Institute of Occupational Health in Oyo State Ministry of Health (Umeokofor et al. 2014b:95). Furthermore, Umeokafor et al. (2014b) 
traced the laws that institutionalised OSH in Nigeria to the promulgation of the Labour Act of 1974. The primary laws that regulate occupational safety and health in Nigeria are The Factories Act of 1987 now The Factories Act of 2004) (Act CAP FLFN 2004). and The Employees' Compensation Act of 2010 (which repeals The Workmen Compensation Act of 2004). The Labour, Safety, Health and Welfare Bill of 2012 is the latest legislation that seeks to repeal The Factories Act of 1990. The Bill was passed into law on 27 September 2012 by the two national legislative arms of the government (Daily Trust 2012). According to the Daily Trust, a national newspaper in Nigeria, the bill seeks to 'repeal and re-enact the factories act of 2004 and to make comprehensive provisions for securing the safety, health, and welfare of persons at work'. However, the bill has not come into force because it has not been assented to by the Executive President as required by the Constitution of the country (Umeokafor et al. 2014a; Ugwu et al. 2020; Colizzi, Lasalvia \& Ruggeri 2020; Hita-Gutiérrez et al. 2020).

\section{Occupational Safety and Health Legislation in Nigeria}

The primary OSH legislation in force according to the online bulletin of the occupational safety and health department in the ministry of labour and employment (2016) includes The Constitution of the Federal republic of Nigeria, (1999), section 17(3c). The health, safety, and welfare of all persons in employment are safeguarded and not endangered or abused. The Principal Factories Act CAP FLFN (2004) and subsidiary legislations include the following: The Declaration of Occupational Diseases Notice (ILO 1956); Factories (Sanitary Accommodation) Regulation (ILO78 1958); First-Aids Boxes (Prescribed Standards) Order (ILO 11-13 78 1958); Docks (Safety of Labour) Regulations (Docks 1958); Factories (Woodwork Machinery) Regulations (ILO16 1987); The Factories (Regulation) Regulations Amendment (OSHP 2004); and Lift, Escalators and Conveyors Safety Regulation (ILO85 1993).

\section{Ratified ILO Conventions}

Nine of the 30 ratified and domesticated ILO conventions still in force include the following nine core conventions and several technical conventions related to social protection measures in Nigeria. These are:

\section{Co81 - Labour Inspection Convention (ILOC081 1947);}


2. Co19 - Equality of Treatment (Accident Compensation) Convention (ILOCC019 1925);

3. Co26 - Minimum Wage-Fixing Machinery Convention (ILOCC026 1928);

4. Co45 - Underground Work (women) Convention (ILOC045 1935);

5. Co95 - Protection of Wages Convention (ILOCC095 1949);

6. Co144 - Tripartite consultations (International Labour Standards) Convention (ILOCC0144 1976);

7. Co155 - Occupational Safety and Health Convention (ILOC155 1981);

8. C0 185 - Seafarers' Identity Documents Convention (Revised) (ILOCC0185 2003); and

9. C0123 - Minimum Age (Underground) Convention (ILOCC0123 1965).

\section{The Factories Act of 1987 (Act CAP FLFN 2004)}

According to Uviehghara (2001), the objective of the Factories Act was to prevent industrial accidents and to ensure safe working environments for the workers. The Act stipulates that the director of factories in the Ministry of Employment, Labour and Productivities have the regulatory power over the location of factories and directs that approval must be received six months before the construction of factories. The Act made more far-reaching provisions for employees' health, safety, and welfare than those of common law, which only specifies employers' duty of care to employees (Uvieghara 2001; Kidd 2020; Simukonda et al. 2020; Supriyatna et al. 2020; Ojo 2020; Umeokafor et al. 2020; Che Ibrahim \& Belayutham 2020).

Furthermore, Uvieghara (2001) writes that the definition of factories as stipulated in the Act is subjected to different legal interpretations. For example, the Factory Act's definition of premises excludes construction activities in its description of factories (Idoro 2011; Umeokafor et al. 2014a; Colizzi et al. 2020; Hita-Gutiérrez et al. 2020; Tella \& Ibinaiye 2020; Nyarubeli et al. 2020; Barros et al. 2020). As such, the construction industry relies on UK/US regulations, which most time is at the discretion of the contractors. The substantial revisions of the Act changed the definition of the factory from an enterprise with ten or more workers to an enterprise with one or more workers, consequently accommodating several small-scale enterprises. The Act also stipulates that there should be an employment relationship for an enterprise to qualify as a factory. For example, the enterprise must have 
a dependent employment relationship between the owners and employees or apprentices. Therefore, technical colleges, university workshops and prisons do not qualify as factories in the definitions given by the Act.

According to Uvieghara (2001: 193 - 195), parts II, III, IV, and V of the Act deal with various aspects of the health, safety, and welfare of workers. The Act widely specifies that management should ensure general provisions in the workplace, which include the following. Employers must provide a clean environment, efficient waste disposal, prevent overcrowding, guarantee proper ventilation, lighting, drainage, sanitary conveniences, proper installation, safeguarding from moving or stationary machinery with hazardous parts. The Act furthermore makes provision for workers' welfare with the provision of portable drinking water, protective clothing and appliances, regulation of first aid, and removal of hazardous fumes (Uvieghara 2001: 228).

The Ministry of Labour and Productivities has the legal responsibility to enforce the provisions of the laws through the directorate of factories units. 'Section 64 creates the offices of a Director of factories of the federation and such inspectors of factories and other officers by designation to enforce the Act' (Univieghara 2001: 239). There are two principal methods for enforcing the Act: administrative enforcement employing factory inspectors, and criminal sanctions for breach of the duties laid down. The Act makes provision for penalties in the event of its contravention. According to Uvieghara (2001: 246), 'when any person is killed or dies or suffer any bodily injuries, occupier or owner is liable without prejudice to any other penalty, to a fine not exceeding N5 000 or imprisonment for a term not exceeding two years or both such fine and imprisonment'.

\section{Employee's Compensation Act, 2010}

Nigeria has made much progress in the legislation on occupational safety and health, especially with the enactment of the Employee's Compensation Act of 2010. The history of compensation of workers for work-related illnesses or accidents dates to the era of occupation health services in Britain in 1897 (Kalejaiye 2013; Reuben et al. 2019; Wekoye et al. 2019; Omoijiade 2019; Osman et al. 2019). It all began when 'Britain's parliament enacted the Health and Morals Act in 1802 to regulate the labour of children and cotton industry' (Kalejaiye 2013:17). In 1833, the British Factories Act was approved. Legislation on compensating workers for injuries and illnesses have been in 
existence for at least a century (Aborisade 2001; Uchendu et al. 2020; Osunwusi 2020; Kakwagh 2020; Ugwu et al. 2020). The doctrine on which compensation of injured workers in British common law had been based is that of 'Negligence liability'. According to Aborisade (2001: 4),

before an employee or his/ her dependents can claim compensation for any injury, the following have to be proved conjunctively: the employer or defender has a duty of care, owed to the worker or claimant, an accident has occurred, the accident was caused because the employer was negligent or failed to practice the duty of care, the accident caused personal injury to the employee.

On the other hand, the employer had traditionally presented three defences under common law. These include 1) Defence of voluntary assumption of risk or violent non-fit injuria; 2) Fellow-servant defence or defence of common employment; and 3) Contributory negligence. The British and Nigerian courts had set aside these three employers' cases to absolve themselves of negligence and subsequent liability. The Workmen Compensation Act, 2010, which repeals the Workmen Compensation Act of 1987, is the principal Act that governs compensation of workers in the event of accidents or sicknesses in Nigeria. Previously, the Workmen's Compensation Act of 1987 was founded on the principle of 'Negligence liability'. The system requires that the claimant has to prove conjunctively that the employer has a duty of care to the employees; that an accident had occurred; that the employer was negligent; and the incident had caused personal injury to the worker. The principle of 'Negligence liability' is arduous to prove, and its repeal represents progress in OSH legislation in Nigeria.

The current legislation, the Employee's Compensation Act, is based on the principle of 'No-fault'. The previous practice of proving negligence has been abolished. The fact that an accident that caused injuries occurred in the workplace is enough reason to claim compensation under the new Act. The act ensures guaranteed payment for any form of injury that is work related, even if it is self-inflicted, except in the case of suicide (Aborisade 2001; Worugii 2013; Wekoye et al. 2019; Fuller 2019; Manu et al. 2019; Simukonda et al. 2020). The Act appointed the Nigeria Social Insurance Fund (NSITF) established by the NSITF of 1993 to manage the fund. The source of the fund, which is governed by the board of the NSITF, includes, 
(a) a take-off grant from the Federal Government;

(b) contributions payable by the employers into the fund;

(c) fees and assessments charged or made according to the act or any regulations of the fund;

(d) the proceeds of investments of the fund; and

(f) any other money that may accrue to the fund from any other sources (Worugji 2013: 34).

Contributions to the fund from workers via employers are $1.0 \%$ of the total monthly payroll in every establishment. According to Worugji (2013: 35) if an employer fails to remit the deductions to the fund, 'Board may impose the penalty in an amount equal to $10 \%$ of the unpaid assessment or the value of the security required (section 46 of the Act)'. Besides, the board can institute a criminal proceeding against an employer to secure quick payment of the assessed contribution.

The Act covers all employees in both the private and public sector, at all levels of governments, and several departments and agencies (Worugju 2013). Though, members of the armed forces and civilian workers in the armed forces are excluded from the Act. The Act primarily covers salaried workers in the formal private and public sectors, thereby excluding the self-employed workforces, including the informal sector. The principal criterion for claiming benefits under the Act is to show that there is 'disabling injury'. According to Worugji (2013: 36), 'disabling injuries cover both physical bodily injuries and other injuries to the mind provided they are work-related'. The general title of the Act states that,

this Act repeals the Workmen's Compensation Act cap W6 laws of the Federation of Nigeria, 2004 and makes comprehensive provisions for payment of compensation to employees who suffer from occupational diseases or sustain injuries arising from an accident at the workplace or in the course of employment.

In the Workmen Compensation Act of 1987, the onus is upon the claimant to prove that the injuries or accidents transpired while in the employ of the company. This insinuates that 'accidents resulting in injuries must occur at the time and place of employment while the employees are doing what he or she is employed to do' (Worugji 2013: 38). On the other hand, the phrase 
'arising out of employment' surmises that 'there must be a causal link or relationship between injury and the work' (Worugji 2013:37). Worugji (2013: 39), found that,

the Employees' Compensation Act has not only put the phrase in disjunctive form by the use of the word 'or' but has gone further to provide that where the injury or disease is caused by accident and the accident arose out of the employment unless the contrary is shown, it shall be presumed that the injury occurred in course of employment (section 7(4) of the Act).

The Act provides for three stages of reporting accidents by the employers and employees concerning claiming compensation from the fund. Firstly, either the employee (or victim of an injury or disabling occupational disease) or the dependent of the victim, in case of death of the victim 'shall' report to the employer or immediate representative or supervisor of the employee within 14 days of occurrence. Following this, the employer 'shall' be required to report to the board and the nearest office of the National Council for Occupational Safety and Health 'within seven days' of occurrence of any injury or disabling occupational disease. The board is defined as the Nigerian Social Insurance Trust Fund Management Board established under the Nigerian Social Insurance Trust Fund Act, 1993. Finally, the completion of a formal application, in the form prescribed by the board, for compensation must be signed by the employee or the employee's dependent and submitted to the board (Aborisade 2001: 8). The criteria for the determination of the scale and quantum of compensation to the injured person or his/her dependents under the Act are not clear (Aborisade 2001; Worugji 2013). The discretional authority bestowed upon the board of the NSITF to prescribe guidelines for mandated reporting systems in the Act was justifiably critiqued by Aborisade (2001). Aborisade (2001) believes that information on procedures in reporting occupational accidents could easily have been obtained from online sources. These results ought to have been incorporated into the Act to avoid any misunderstanding in the incident lapses by the board. According to Worugji (2013: 39), the category of compensation for injuries that claimants can apply for under the Act includes the following: a) Fatal cases, b) Permanent total disability, c) Permanent partial disability or disfigurement; and d) Temporary disability (which may be complete or partial). 
Worugji (2013) inscribes that eligibility for dependents claiming compensation was established on the conjecture of a monogamous family. Further to this, he argues that such an assumption is not realistic, because Nigerians are known to be involved in polygamous relationships. He also pronounces that the new Act departs from the lump sum payment system to a monthly payment system. He observes that the new Act did not factor the cost of inflation into the monthly payment. The Act protects the right of workers to guaranteed compensation. The Act provides a statute bar of one year for injured employees to file for compensation and not more than three years after the date of a worker. However, a special waiver can be granted by the board if new evidence is provided by experts to support an application for compensation under exceptional circumstances. The Act also provides a system of dispute resolution concerning the claimant's application. According to Worugji (2013: 43), the Act offers two forms of appeals. The first appeal, which must 'be in writing to the Board within 180 days of the date of the decision complained of otherwise the right of appeal would be lost' to review her decision and the second appeal will be to the National Industrial Court (s.55 of the Act). The arrangement is quite different under the Workmen Compensation Act of 1987, where the High Court has jurisdictions of broad civil matters, including labour-related matters. The former system was fraught with delays and it usually took a long time to get decisions.

The Employees' Compensation Act of 2010 is a highly ambitious and innovative piece of legislation that seeks to prevent industrial accidents. It provides a fair and quick system of compensation in the eventuality of injuries, diseases, mental stress and physical impairment that are work related and have occurred in any establishment. The Act is in line with international ILO conventions such as the Employment Injuries Benefit Convention 1964 (c121) as amended (Worugji 2013; Tella \& Ibinaiye 2020; Nyarubeli et al. 2020; Barros et al. 2020; Nkuhi \& Benjamin 2020; Umeokafor 2020). The challenge is getting both the institutional and bureaucratic arrangements in place for the effective implementation of the Act (Worugji 2013; Colizzi et al. 2020; HitaGutiérrez et al. 2020). The next section will discuss the enforcement of OSH legislation in Nigeria.

\section{Regulations of Occupational Safety and Health in Nigeria}

There is a consensus among scholars that the enforcement of OSH legislation 
in Nigeria is weak (Umeokafor, Umeadi \& Jones 2014b; Aniekwu 2007; Adei \& Kunfaa 2007; Abubakar 2015, Idoro 2011), particularly in the construction industry, which has been omitted from existing OSH legislation in Nigeria. According to Umeokafor et al. (2014b), the enforcement of OSH regulations includes 'warning or notices to offenders and searching a defaulting factory'. They further write that most of the administrative process was ineffective as a result of inadequate inspectorate departments to enforce the sanction. Nigeria had 39 factory inspectors and 5888 registered factories in the six geographical zones, according to the 2006 National Occupational and Safety and Health Information Report. Table 2 displays the workforce analysis of the inspectorate department in the Ministry of Labour and Employment.

Table 2: Number of Registered Factories and Inspectors in Six Geographical Zones in Nigeria

\begin{tabular}{|l|r|c|}
\hline Geographical Zone & $\begin{array}{l}\text { Registered } \\
\text { Factories }\end{array}$ & Number of Inspectors \\
\hline South-West & 2777 & 22 \\
\hline South-East & 922 & 5 \\
\hline South-South & 524 & 2 \\
\hline North-West & 868 & 5 \\
\hline North-East & 252 & 2 \\
\hline North Central & 509 & 1 \\
\hline Federal Capital Territory & 36 & 39 \\
\hline Total & 5,888 & \\
\hline
\end{tabular}

Source: National Bureau of Statistics (2014)

The two central bodies that enforce OSH regulations in Nigeria are the factory inspectorate in the Ministry of Labour and Employment and the Nigeria Social Insurance Trust Fund (NSITF). In a review, Umeokafor et al. (2014b: 102) identifies the factors that contribute to weak regulation of $\mathrm{OSH}$ to be 'social-cultural, socio-economic, institutional/legal and organisational issues'. They further identify the specific causes of weak enforcement of OSH regulations in Nigeria to include inadequate factory inspectors, political interference in $\mathrm{OSH}$ regulations, slow judicial processes, prevalent corruption and bribery in the country, insufficient government funding, inadequate 
legislation, insufficient government commitment, general insecurity in the country, lack of a national OSH information system, rapid technological and economic growth, and a culture of poor safety. Abubakar (2015), in a review of OSH systems of Nigeria, UK, USA, Australia and China, compares the various aspects of $\mathrm{OSH}$ systems in these countries along the following dimensions: financial issues, litigation delay, and lack of technical and risk specialists. He notes that developing countries such as Nigeria have weak OSH systems along the identified dimensions. After that Abubakar (2015: 1356 1357) suggests critical factors for an effective OSH system to include:
1) Adequacy of the OSH law(s);
2) The efficiency of the judicial system;
3) Degree of independence of the OSH regulatory agency;
4) Structure and placement of the regulatory and enforcement bodies;
5) Adequacy of budgetary allocation;
6) Accident history and government sensitivity;
7) Good workforce-inspector ratio; and
8) Activities of the civil society and human rights groups.

The ILO has remained committed to promoting and inspiring member states to develop national OSH systems through ILO instruments such as a 'Promotion framework for occupational safety and health convention' (ILOC187 2006; Machida 2009: 4). Machida (2009: 4) further posits that the key parts of these ILO instruments include 'the development of national OSH policy, national OSH program. And national OSH systems by the government, in consultation with social partners'. The next section will review the accident reporting system in Nigeria.

\section{OSH Reporting System in Nigeria}

Nigeria does not have an online, nationally integrated OSH reporting system in place (Abubakar 2015). Although the Factories Act of 1990 makes reporting of accidents mandatory. Evidence displays that the provision is disregarded; as a result, industrial accident data are mostly under-reported. According to Aniekwu (2007), accidents data are not available, and when possible, they are not reliable as a result of under-reporting. However, Abubakar (2015) points out that biographical data can be located in the national bureau of statistics and 
accessed via the health management information system in Nigeria. Table 3 below displays the social security provision activities in 2013 reported by the Nigerian Ministry of Labour and Employment (2016).

\section{Table 3: Social Security Provision Activities between}

January-December 2013

\begin{tabular}{|l|l|l|l|}
\hline Output to outcome & Target & Achievement & Remarks \\
\hline $\begin{array}{l}\text { Number of people } \\
\text { benefiting from the } \\
\text { Employee } \\
\text { Compensation } \\
\text { Programme of NSITF }\end{array}$ & 5340000 & 3500000 & $65.5 \%$ \\
\hline $\begin{array}{l}\text { People benefiting from } \\
\text { various social security } \\
\text { schemes }\end{array}$ & 75000000 & 23000000 & $30.6 \%$ \\
\hline $\begin{array}{l}\text { Number of } \\
\text { resettlement claims } \\
\text { paid }\end{array}$ & 10750 & 10750 & $100 \%$ \\
\hline
\end{tabular}

Source: Ministry of Labour and Employment, 2016

The OSH system in Nigeria is very similar to those of other developing countries. The challenge of institutionalising an effective OSH system starts from the adequacy of the legislation; if they are on par with ILO standards. The realisation of the inadequacy of the Factory Act of 1990 prompted the national legislative arm in Nigeria to pass the Occupational Safety and Health Bill, which is still awaiting the president's assent before it can be implemented in the country. The Employees' Compensation Act is evidence of significant progress in the OSH system in Nigeria. However, weak enforcement and lack of an online national database are some of the challenges that need to be confronted in the country.

\section{Occupational Safety and Health System in the Food and Drink Industry in Nigeria}

The food and drink industry consists of enterprises that process agricultural raw materials to finished goods (CIAA 2002). According to the CIAA report 
(2002), there were 60 registered food and drink companies in Nigeria, compared to South Africa that has 1800 registered companies. The industry is controlled mainly by multinationals from the European Union, Asia and South Africa. The food and drink sub-sector were the most significant contributor to the country's GDP out of the total manufacturing sector (NBS 2014). The sector is still undeveloped with much emphasis on the importation of consumers' goods. The CIAA (2002) report further states that the capacity utilisation of the manufacturing sector in Nigeria recorded an average of 53\% in 2010. Some of the challenges in the sector include the high cost of production, inadequate energy supply, weak infrastructure, and inconsistent government policies. The central regulators in the industry include the National Agency for Food and Drug Administration (NAFDAC 2004) and the Standard Organization of Nigeria (ISO 1982). NAFDAC (2004) is the body responsible for registering and regulating all consumers' goods and drugs, whether produced locally or internationally for the Nigerian market (Gain report). The Standard Organization of Nigeria (ISO 1982) is a government agency that promotes the standardisation and quality of industrial products for the Nigerian market (Chete et al. 2013). The composition of consumer goods in the Nigerian food and drink industry includes beer, soft drink, cereals, etc.

\section{Industrial Relations System}

The Nigerian IR system was established during British colonial rule over the country between 1914 and 1960;. This occurred alongside the imposition of Anglo-Saxon institutions and legal frameworks on the people of Nigeria (Ubeku 1983). The IR system was modelled on the well-established existing British principles of voluntarism. The IR system procured a different technique following the Nigerian Civil War (1967-70) when the then military administration employed radical changes. The current IR system was established through the promulgation of statutes such as The Labour Act of 1974, The Trade Dispute Act of 1973, and The Trade Union Degree 22 of 1978. The new policy direction was reliant on 'government involvement and limited intervention' (Ubeku 1983). The industry subscribes to traditional institutional forms of regulating employment relations, including safety issues through structures that allow direct consultation between employers' association and workers' organisation in the sector. The association of food, beverage and tobacco employers (AFBTE) is the registered employers' association that 
represents the interest of employers on labour-related matters. Two registered trade unions represent workers in the Nigerian industry. The first is the food, Beverages and Tobacco Senior Staff Association (FOBTOB) and the second represents the National Union of Food, Beverage and Tobacco Employees of Nigeria (NUFBTEN) registered unions that represent both white and bluecollar workers, respectively. FOBTOP is a white-collar union that is affiliated to trade union congress of Nigeria (TUCN), a labour centre for white-collar workers in the country. NUFBTEN is a registered union that represents production workers that are allied to the Nigerian labour congress (NLC), the largest labour centre in the country that represents the blue-collar workers in Nigeria.

\section{Dispute Resolution Mechanism}

The Trade Union Dispute Act of 1973 is the primary mechanism for resolving the industrial dispute in the industry. The Act made provision for private and statutory dispute resolution mechanisms. The private mechanism encompasses procedures devised in the enterprise as delimited in their employment statute policy for settling the conflict. The statutory mechanism comprises the processes of conciliation, mediation, and arbitration. The statutory institutions responsible for dispute resolutions include the industrial arbitration panel (IAP) and the national industrial court (NIC 2016). The NIC (2016) is the Supreme Appeal Court on labour matters in the country, excluding issues that contravene fundamental human rights (NIC 2016). A perfunctory appraisal of the NIC (2016) resolutions between 2015-16 demonstrates that a record number of the disputes filed at the court concentrated on wrongful dismissal, wrongful termination of employment and determination of procedural rules on industrial action. Most industrial accidents were under-reported and scarcely referenced in labour laws reviews.

Table 4: Category of Cases Filed Between 2015-16 at the NIC

\begin{tabular}{|c|l|l|l|}
\hline SN & Enterprise/Association & Dispute & Suit Number \\
\hline $\mathbf{1}$ & $\begin{array}{l}\text { Niger Mills Company } \\
\text { Limited }\end{array}$ & $\begin{array}{l}\text { Wrongful } \\
\text { termination of } \\
\text { employment }\end{array}$ & NICN/CA/97/2013 \\
\hline
\end{tabular}


Qudus Olawepo, Mariam Seedat-Kahn \& Stanley Ehiane

\begin{tabular}{|c|l|l|l|}
\hline $\mathbf{2}$ & Nestle Nigeria Plant & NICN/LA/198/2013 \\
\hline $\mathbf{3}$ & $\begin{array}{l}\text { Nigeria Bottling } \\
\text { Company Limited }\end{array}$ & $\begin{array}{l}\text { Wrongful } \\
\text { termination of } \\
\text { employment }\end{array}$ & NICN/EN/126/2014 \\
\hline $\mathbf{4}$ & Nigeria Breweries Plant & $\begin{array}{l}\text { Wrongful } \\
\text { termination of } \\
\text { employment }\end{array}$ & NICN/OW/53/2014 \\
\hline $\mathbf{5}$ & AFBTE and FOBTOP & $\begin{array}{l}\text { Procedural rules } \\
\text { on industrial } \\
\text { actions }\end{array}$ & NICN/LA/285/2014 \\
\hline $\mathbf{6}$ & Sara Foods Limited & $\begin{array}{l}\text { Wrongful } \\
\text { termination of } \\
\text { employment }\end{array}$ & NICN/LA/388/2012 \\
\hline $\mathbf{7}$ & Seven-up Bottling Plant & $\begin{array}{l}\text { Wrongful } \\
\text { dismissal }\end{array}$ & NICN/ABJ/231/2012 \\
\hline
\end{tabular}

Source: NIC (2016)

The labour laws established the standard for the relationships between labour and capital through the various agencies that regulate these dynamic and complex IR. Safety issues hardly make bargainable tripartite discussions during wages and salaries negotiation. The statutory bodies that were established by law have been inefficient due to paucity of funds, shortage workforce, weak management and general administrative bottlenecks. Victims of workplace accidents suffer in silence with little or no compensation. Most of the employees do not have trade union protection due to the atypical nature of employment nature in the country.

\section{Conclusion}

This paper offered exacting details of the occupational safety and health system in existence in Nigeria. The setting of the food and drink industry and the form of the IR system in Nigeria were similarly explored. The assessment of pertinent ILO occupational safety and health conventions include convention Number 155 (ILOC155 1981) and the promotional framework for OSH convention Number 187 (ILOC187 2006). The assessment recognised and confirmed with certainty the weakness of Nigeria's OSH systems. The wide- 
ranging administrative, logistical and operational constrictions that impede the efficient implementation of occupational health and safety systems are acknowledged. These impediments thwart Nigeria and other African countries capacity to ratify the promotional Framework for Occupational Safety and Health Convention Number 187 of 2006 (ILOC187 2006). Convention 187 (ILOC187 2006) makes it mandatory for ratifying members' state to formulate national occupational safety and health policies, systems, and programmes to prevent industrial accidents and minimise hazardous workplace conditions. Specifically, the convention makes it mandatory for a coherent national occupational safety and health system once adopted.

\section{Recommendations}

Bearing in mind the inferences from the exhaustive scholarship review presented, the subsequent recommendations have been carefully formulated to proposition a clinical approach to improving safety systems in Nigeria. The Factories Act of 1987 (Act CAP FLFN 2004) provides penalties for the breach of any provisions of the act. According to Uvieghara (2001: 246),

when any person is killed or dies or suffers any bodily injuries, the occupier or owner is liable without prejudice to any other penalty, to a fine not exceeding two years or both such fine and imprisonment.

This seems to be an unreasonable if not impossible compensation for human life; it is therefore advocated that these outdated laws be rescinded, and stateof-the-art contemporary laws that safeguard the workers be enacted. Without a committed legal framework supported by the government, The Factories Act of 1990, which requires mandatory reporting of all industrial accidents, will continue to be disregarded. This contravention results in under-reported and inaccurate data, which will continue to compromise occupational health and safety standards. Nigeria must cultivate an online nationally integrated OSH recording system, that compels employers to chronicle industrial accidents systematically. A recording system is imperative, primarily because Nigeria has a paltry 39 factory inspectors in service. These inspectors are tasked with the responsibility of the country's 5888 registered factories. The factories are dispersed throughout the six geo-political zones of Nigeria. This inconse- 
quential number of 39 factory inspectors is appallingly low and cannot effectively regulate and monitor all 5888 registered factories with any logic of exactitude. The urgency of added factory inspectors must be engaged in each of the six zones. The challenge is that Nigeria, like other African countries have not ratified the OSH principal prescribed by the ILO convention on OSH 1981 (ILOC155 1981). and the ILO promotional framework for OSH convention, 2006 (ILOC187 2006). Nigeria and her African neighbours are likely to benefit fiscally by remedying the contravention of inaccurate reporting of industrial accidents.

\section{References}

Aborisade, F. 2010. Employee's Compensation Act, 2010: Progress or Retrogression? Kolagbodi Annual Memorial Lecture. Unpublished.

Abubakar, U. 2015. An Overview of the Occupational Safety and Health Systems of Nigeria, UK, USA, Australia and China: Nigeria being the Reference Case study. American Journal of Education Research 3,11: $1350-1358$.

Adei, D. \& E. Kunfaa 2007. Occupational Health and Safety Policy in The Operations of the Wood Processing Industry. In Kumasi, Journal of Science and Technology 27,2: $161-173$.

https://doi.org/10.4314/just.v27i2.33052

Aniekwu, N. 2007. Accidents and Safety Violations in Nigerian Construction Industry. Journal of Science and Technology 27,1: 81 - 89.

https://doi.org/10.4314/just.v27i1.33027

Bamel, U.K, R. Pandey \& A. Gupta 2020. Safety Climate: Systematic Literature Network Analysis of 38 Years (1980-2018) of Research. Accident Analysis \& Prevention 135,10: 53 - 87.

https://doi.org/10.1016/j.aap.2019.105387 PMid:31838322

Barros, B., A. Dores \& M. Rodrigues 2020. Effects of Safety and Health Training in Metalworking Small-Sized Enterprises. International Journal of Occupational and Environmental Safety 4,1: 48 - 61.

https://doi.org/10.24840/2184-0954_004.001_0004

Che Ibrahim, C.K.I. \& S. Belayutham 2020. A Knowledge, Attitude and Practices (KAP) Study on Prevention Through Design: A Dynamic Insight into Civil and Structural Engineers in Malaysia. Architectural Engineering and Design Management, 16,2: 131 - 149. 
An Overview of Occupational Safety and Health Systems in Nigeria

https://doi.org/10.1080/17452007.2019.1628001

Chete, L., J. Adeoti, F. Adeyinka \& O. Ogundele 2013. Industrial Development and Growth in Nigeria: Lessons and Challenges. Ibadan: Nigerian Institute of Social and Economic Research (NISER).

https://doi.org/10.35188/UNU-WIDER/2014/740-0

CIAA, Confederation of the Food and Drink Industries of the EU 2002. Industry as A Partner for Sustainable Development: Food and Drink. United Kingdom. Available at: http://www.ciaa.be (Accessed 4 May 2020.)

Colizzi, M., A. Lasalvia \& M. Ruggeri 2020. Prevention and Early Intervention in Youth Mental Health: Is It Time for A Multidisciplinary and TransDiagnostic Model for Care? International Journal of Mental Health Systems, 14, 2: 1 - 14. https://doi.org/10.1186/s13033-020-00356-9

PMid:32226481 PMCid:PMC7092613

Constitution of the Federal Republic of Nigeria. 1999. Available at:

http://www.nigerialaw.org/ConstitutionOfTheFederalRepublicOfNigeria htm (Accessed 4 May 2020.)

Daily Trust. 2012. Senate Passes Labour and Safety Act. Available at: https://dailytrust.com (Accessed 4 May 2020.)

Docks 1958. (Safety of Labour) Regulations. Available at:

https://gazettes.africa/gazettes/ng-government-gazette-supplement-

dated-1958-05-29-no-40-part-b (Accessed 4 May 2020.)

Ezenwa, A.O. 2001. A Study of Fatal Injuries in Nigerian Factories. Society of Occupational Medicine 51,8: 485 - 489.

https://doi.org/10.1093/occmed/51.8.485 PMid:11741079

Factories Act. 1987. Laws of Nigeria. Available at:

https://lawsofnigeria.placng.org/laws/F1.pdf (Accessed 4 May 2020.)

Fuller, T.P. (ed.) 2019. Global Occupational Safety and Health Management Handbook. CRC Press. https://doi.org/10.1201/9780429056475

Hallowell, S, M. Bhandaeri \& W. Alrugi 2019. Global Differences in Risk Tolerance Levels Among Construction Workers. Conference Paper. Available at:

https://www.researchgate.net/publication/333809039_GLOBAL_DIF (Accessed 4 May 2020.)

Hamalainen, P., J. Takala \& K. Saarela 2006. Global Estimates of Occupational Accidents. Safety Science 44,1: 137 - 156.

https://doi.org/10.1016/j.ssci.2005.08.017 
Hammarskjold, D. 2013. It Is When We All Play Safe that We Create a World of Utmost Insecurity. In Malik, K. (ed.): Human Development Report: The Rise of The South: Human Progress in A Diverse World. USA: United Nations Development Programme.

Hita-Gutiérrez, M., M. Gómez-Galán, M, Díaz-Pérez, \& A.J. Callejón-Ferre 2020. An Overview of Reba Method Applications in The World. International Journal of Environmental Research and Public Health 17,8: 26-35. https://doi.org/10.3390/ijerph17082635

PMid:32290561 PMCid:PMC7215911

Idoro, G. 2011. Comparing Occupational Health and Safety (OHS) Management Efforts and Performance of Nigerian Construction Contractors. Journal of Construction in Developing Countries 16,2: 151 - 173.

ILOC017. 1925. Workmen's Compensation (Accidents) Convention, 1925 Available at:

https://www.ilo.org/dyn/normlex/en/f?p=NORMLEXPUB:12100:0::NO $\because$ P12100 ILO CODE:C017 (Accessed 4 May 2020.)

ILOCC019. 1925. Co19 - Equality of Treatment Accident Compensation Convention 1925. Available at:

https://www.ilo.org/dyn/normlex/en/f?p=NORMLEXPUB:12100:0::NO $\because:$ P12100_ILO_CODE:C019 (Accessed 4 May 2020.)

ILOCC026. 1928. Co26 - Minimum Wage-Fixing Machinery Convention 1928. Available at:

https://www.ilo.org/dyn/normlex/en/f?p=NORMLEXPUB:14001:0::NO $\because$ P14001_INSTRUMENT_ID:312171 (Accessed 4 May 2020.)

ILOC045. 1935. Underground Work (Women) Convention, 1935 (No. 45). Available at:

https://www.ilo.org/dyn/normlex/en/f?p=NORMLEXPUB:12100:0::NO P12100 ILO CODE:C045 (Accessed 4 May 2020.)

ILOC081. 1947. C081 - Labour Inspection Convention, 1947 (No. 81). Available at: https://www.ilo.org/dyn/normlex/en/f?p=NORMLEXPUB:12100:0::NO $\because$ P12100 ILO CODE:C081 (Accessed 4 May 2020.)

ILOCC095. 1949. Co95 - Protection of Wages Convention (1949). Retrieved from

https://www.ilo.org/dyn/normlex/en/f?p=1000:12100:::NO:12100:P1210 0 INSTRUMENT ID:312240 (Accessed 4 May 2020.)

ILOR097. 1953. Protection of Workers' Health Recommendation, 1953 (No. 
An Overview of Occupational Safety and Health Systems in Nigeria

97) Available at:

https://www.ilo.org/dyn/normlex/en/f?p=1000:12100:::NO:12100:P1210

0 INSTRUMENT ID:312435 (Accessed 4 May 2020.)

ILO 1956. The Declaration of Occupational Diseases Notice. Available at: https://www.ilo.org/wcmsp5/groups/public/---africa/---ro-abidjan/---iloabuja/documents/publication/wcms_552748.pdf (Accessed 4 May 2020.)

ILO 11-13 78 1958. First-Aids Boxes (Prescribed Standards) Order. Available at: https://gazettes.africa/archive/ng/1958/ng-government-gazette-dated1958-11-13-no-78.pdf (Accessed 4 May 2020.)

ILO78 1958. Factories (Sanitary Accommodation) Regulation. Available at: https://gazettes.africa/gazettes/ng-government-gazette-dated-1958-1113-no-78 (Accessed 4 May 2020.)

ILOC119. 1963. Guarding of Machinery Convention, 1963 (No. 119). Available at:

https://www.ilo.org/dyn/normlex/en/f?p=NORMLEXPUB:55:0:::55:P55 TYPE,P55 LANG,P55 DOCUMENT,P55 NODE:CON,en,C119,/Do cument (Accessed 4 May 2020.)

ILOCC0123. 1965. C0123 - Minimum Age (Underground) Convention 1965. Available at:

https://www.ilo.org/dyn/normlex/en/f?p=NORMLEXPUB:12100:0::NO $:$ P12100_ILO_CODE:C123

(Accessed 4 May 2020.)

ILOCC0144. 1976. Co144 - Tripartite consultations International Labour Standards Convention 1976. Available at:

https://www.ilo.org/dyn/normlex/en/f?p=NORMLEXPUB:11300:::NO:

11300:P11300 INSTRUMENT ID:312240:NO (Accessed 4 May 2020.)

ILOC155. 1981.Occupational Safety and Health Convention, 1981 (No. 155). Available at: ILO85 1993. Lift, Escalators and Conveyors Safety Regulation. Available at:

https://www.nioh.ac.za/wp-content/uploads/2020/03/liftescallator.pdf http://www.ilo.org

(Accessed 4 May 2020.)

https://www.ilo.org/dyn/normlex/en/f?p=NORMLEXPUB:12100:0::NO $\because:$ P12100 ILO CODE:C155 (Accessed 4 May 2020.)

ISO. 1982. Standards Organisation of Nigeria. Available at:

https://www.iso.org/member/1982.html (Accessed 4 May 2020.) 
ILOR721. 1986. R172 - Asbestos Recommendation, 1986 (No. 172). Available at:

https://www.ilo.org/dyn/normlex/en/f?p=1000:12100:::NO:12100:P1210 0_INSTRUMENT_ID:312510 (Accessed 4 May 2020.)

ILO16 1987. Factories (Woodwork Machinery) Regulations. Available at: http://www.ilo.org (Accessed 4 May 2020.)

ILOCC0185. 2003. C0 185 - Seafarers' Identity Documents Convention (Revised) (2003). Available at:

https://www.ilo.org/dyn/normlex/en/f?p=NORMLEXPUB:12100:0::NO $\because$ P12100_INSTRUMENT_ID:312330 (Accessed 4 May 2020.)

ITC. 2004. Supreme Court of Justice, Aquino, Isacio v. Cargo Servicios Industriales S.A., 21 September 2004, A. 2652. XXXVIII. Available at: https://compendium.itcilo.org/en/compendium-decisions/supreme-courtaquino-isacio-v.-cargo-servicios-industriales-s.a.-21-september-2004-a.2652.-xxxviii (Accessed 4 May 2020.)

ILOC187. 2006. C187 - Promotional Framework for Occupational Safety and Health Convention, 2006 (No. 187). Available at:

https://www.ilo.org/dyn/normlex/en/f?p=NORMLEXPUB:12100:0::NO $\because$ P12100 ILO CODE:C187 (Accessed 4 May 2020.)

International Labour Organization. 2019. Global Standards. Available at: http://ilo.org/global/standards/subjects-covered-by-international-lab (Accessed 4 May 2020.)

International Labour Organization. 2020. Application of International Labour Standards 2020. Available at:

https://www.ilo.org/wcmsp5/groups/public/---ed_norm/--relconf/documents/meetingdocument/wcms 736204.pdf

(Accessed 4 May 2020.)

Kakwagh, V.V. 2020. Occupational Health Hazards of Women Farmers in Ankpa Local Government Area of Kogi State - Nigeria. Bangladesh Sociological Society 17,1: $197-208$.

Kalejaiye, P. 2013. Occupational Health and Safety: Issues, Challenges and Compensation in Nigeria. Peak Journal of Public Health and Management 1,2: 16 - 23 .

Kidd, M. 2020. The Contribution of Family Medicine to Improving Health Systems: A Guidebook from The World Organization of Family Doctors.

CRC Press. https://doi.org/10.1201/9780429084201-2

Machida, S. 2009. System for Collection and Analysis of Occupational 
An Overview of Occupational Safety and Health Systems in Nigeria

Accidents. In Joronen, M. (ed.): African Newsletter on Occupational Health and Safety 19,1: 27-35.

Manu, P, A. Poghosyan, I.M. Mshelia, S.T. IIwo, A.M. Mahamadu \& K. Dziekonski 2019. Design for Occupational Safety and Health of Workers in Construction in Developing Countries: A Study of Architects in Nigeria. International Journal of Occupational Safety and Ergonomics 25,1: 99 - 109. https://doi.org/10.1080/10803548.2018.1485992 PMid:29902120

Ministry of Labour and Employment 2016. Department of Occupational Safety and Health. Available at: http://www.labour.gov.ng (Accessed 4 May 2020.)

NAFDAC. 2004. The National Agency for Food and Drug Administration and Control Act Cap N1 Laws of the Federation of Nigeria (LFN). Available at: https://www.nafdac.gov.ng/about-nafdac/ (Accessed 4 May 2020.)

NBS, National Bureau of Statistics 2014. Nigerian Manufacturing Sector: Summary Report 2010-2013. Available at: http://www.nigerianstat.gov.ng/report/260 (Accessed 4 May 2020.)

NIC National Industrial Court. 2016. Available at: http://www.judgement.nicn.gov.ng/cont-dtl.php?cont.c-80 (Accessed 1 June 2020.)

NOSH, 2016. National Occupational Safety and Health Information Centre Report on Nigeria. 2016. Available at:

https://www.ilo.org/legacy/english/protection/safework/cis/about/mtg20 06/pnga_mlpid.pdf (Accessed 4 May 2020.)

Nkuhi, M.S. \& M.S. Benjamin 2020. Disorders in Developing Countries' Legal and Regulatory Frameworks on Protection of Workers' Health and Safety. East African Journal of Social and Applied Sciences 2,1: 1 - 12. Nyarubeli, I.P., A.M. Tungu, M. Bråtveit \& B.E. Moen 2020. Occupational Noise Exposure and Hearing Loss: A Study of Knowledge, Attitude and Practice among Tanzanian Iron and Steel Workers. Archives of Environmental and Occupational Health 75,4: 216 - 225.

https://doi.org/10.1080/19338244.2019.1607816

PMid:31033430

O'Connor, F.S. 2014. The ILO'S Activities on Occupational and WorkRelated Diseases. International Labour Organization. Available at: http://www.ilo.org/global/topics/safety-and-health-at-work/lanfen/index.htm (Accessed 4 May 2020.) 
Ojo, S. 2020. Returnee Entrepreneurship and Workplace Health and Safety in Nigeria. Available at:

https://sk.sagepub.com/cases/returnee-entrepreneurship-and-workplacehealth-and-safety-in-nigeria

(Accessed 4 May 2020.) https://doi.org/10.4135/9781529715842

Okoye, P.U, J.U. Ezeokonkwo \& F.O. Ezeokoli 2016. Building Construction

Workers' Health and Safety Knowledge and Compliance on Site. Journal of Safety Engineering 5,1: 7 - 26.

Omoijiade, E.N. 2019. A Comparative Study of the Hazards Management System Associated with Laundry Operations in Secondary and Tertiary Health Facilities in Nigeria. Journal of Health Research and Reviews 6,1: 1 - 11. https://doi.org/10.4103/jhrr.jhrr_48_18

Omokhodion, F. 2009. Occupational Health in Nigeria. Society of Occupational Medicine 59,1: 201.

https://doi.org/10.1093/occmed/kqn178

OSHP Occupational Safety and Health Protection of The National Labour Force 2004. The Factories Regulations Amendment. Available at: https://archive.gazettes.africa/archive/ng/2018/ng-government-gazettedated-2018-01-11-no-6.pdf (Accessed 4 May 2020.)

Osunwusi, A.O. 2020. Occupational Radiation Exposures in Aviation: Air Traffic Safety Systems Considerations. International Journal of Aviation, Aeronautics, and Aerospace 7,2:1-6.

Pearson, K. 2009. The Causes and Incidence of Occupational Accidents and Ill-Health Across the Globe. London: British Safety Council.

Reuben, U.F, A. Ismail, A.L. Ahmad, H.M. Maina \& A. Daud 2019. Occupational and Environmental Risk Factors Influencing the Inducement of Erythema among Nigerian Laboratory University Workers with Multiple Chemical Exposures. International Journal of Environmental Research and Public Health 16,8: $13-34$.

https://doi.org/10.3390/ijerph16081334

PMid:31013942 PMCid:PMC6518193

Sector Report of Fast-Moving Consumer Goods in Africa. Available at: http://www.kpmg.com/africa (Accessed 4 May 2020.)

Simukonda, W., P. Manu, A.M. Mahamadu \& K. Dziekonski 2020. Occupational Safety and Health Management in Developing Countries: A Study of Construction Companies in Malawi. International Journal of Occupational Safety and Ergonomics 26,2: 303 - 318. 
https://doi.org/10.1080/10803548.2018.1482649 PMid:29846152

Supriyatna, H., W. Kurniawan \& H.H. Purba 2020. Occupational Safety and Health Risk in Building Construction Project: Literature Review. Operational Research in Engineering Sciences: Theory and Applications, 3,1: 28 - 40. https://doi.org/10.31181/oresta200134s

Talaka, J. 1999. Global Estimates of Fatal Occupational Accidents. Geneva, Switzerland: International Labour Office.

Talaka, J. 2005. Global Estimates of Traditional Occupational Risks. Geneva: Switzerland: International Labour Office.

Tella, A. \& O.A. Ibinaiye 2020. Correlates of Staff Motivation, Satisfaction, and Job Performance of Library Staff in Selected Nigerian University Libraries. International Information and Library Review 52,1: 32 - 49.

Act CAP FLFN.2004. The Principal Factories Act CAP FLFN. Available at: https://lawsofNigeria.placng.org (Accessed 4 May 2020.)

Ubeku, A.K. 1983. Industrial Relations in Developing Countries: The Case of Nigeria. England: Springer. https://doi.org/10.1007/978-1-349-17265-8

Uchendu, C., R. Windle \& H. Blake 2020. Perceived Facilitators and Barriers to Nigerian Nurses' Engagement in Health Promoting Behaviours: A Socio-Ecological Model Approach. International Journal of Environmental Research and Public Health 17,4: 1314.

https://doi.org/10.3390/ijerph17041314

PMid:32085607 PMCid:PMC7068510

Ugwu, F.O., A.N. Idike, O.E. Ibiam, F.A. Akwara \& C.O. Okorie 2020. Transformational Leadership and Management Safety Practices: Their Role in The Relationship Between Work Pressure and Compliance with Safety Work Behaviour in A Health-Care Sector Industry. Journal of Psychology in Africa 30,1: 1 - 8 .

https://doi.org/10.1080/14330237.2020.1716551

Umeokafor, N., B. Umeadi \& R. Jones 2014a. Compliance with Occupational Safety and Health Regulations: A Review of Nigeria's Construction Industry. Proceedings of the $3^{\text {rd }}$ International Conference on Infrastructure Development in Africa. Abeokuta: Nigeria.

Umeokafor, N. D. Issac, K. Jones \& B.N. Umeadi 2014b. Enforcement of Occupational Safety and Health Regulations in Nigeria: An Exploration. European Scientific Journal 3,1: 93 - 104.

Umeokafor, N. 2020. Why Copied or Transposed Safety, Health and Wellbeing Legislation and Standards are Impracticable and Irrelevant in 
Developing Economies. Policy and Practice in Health and Safety 18,1: $41-54$.

https://doi.org/10.1080/14773996.2019.1667095

Umeokafor, N., K, Evangelinos \& A. Windapo 2020. Strategies for Improving

Complex Construction Health and Safety Regulatory Environments.

International Journal of Construction Management 30:1 - 12.

https://doi.org/10.1080/15623599.2019.1707853

United Nations Development Programme 2019. Human Development Index

Report. Available at: http://www.bw.undp.org

(Accessed 4 May 2020.)

Osman, M.M.B., A.G. Salaudeen, B.F. Rotimi, A.O. Uthman, H.K. Oloyede,

T.P. Omojasola \& O.I. Musa 2019. Effect of Training on Knowledge,

Attitude and Practice of Safety Measures among Battery Chargers in Ilorin Metropolis. Research Journal of Health Sciences 7,2: 126 - 136.

https://doi.org/10.4314/rejhs.v7i2.7

Uvieghara, A. 2001. Labour Law in Nigeria. Lagos: Malthouse Press Ltd.

Victor, A.Y. 2013. Workplace in Nigeria Unsafe, Labour Lament. Vanguard

Newspaper. Available at:

http://www.vanguardngr.com/2013/06/workplaces-in-nigeria-unsafe-

lament-labour

(Accessed 4 May 2020.)

Wekoye, S.A., W.N. Moturi \& S. Makindi 2019. Factors Influencing Non-

Compliance to Occupational Safety and Health Practices in the Informal

Non-Food Manufacturing Sector In Kampala City, Uganda. Current

Journal of Applied Science and Technology, 3: 1 - 12.

https://doi.org/10.9734/cjast/2019/v36i630266

Worujgi, N.E. 2013. Work Injuries Compensation Under the Employee's Compensation Act in Nigeria: What Next? Journal of Law, Policy and Globalization 10:30-45.

Qudus Olawepo The University of KwaZulu-Natal Society and Social Change Durban South Africa wale.olawepo@gmail.com 
An Overview of Occupational Safety and Health Systems in Nigeria

Professor Mariam Seedat-Khan CCS The University of KwaZulu-Natal Society and Social Change Durban, South Africa Seedatm@ukzn.ac.za

Stanley Ehiane Fort Hare Institute of Social and Economic Research (FHISER) University of Fort Hare Eastern Cape, South Africa Stanleyehiane@yahoo.com 